\title{
The sustainable technological model (DESUSTEC) as a tool in the development of software for the reduction of electronic waste
}

\section{El modelo sustentable tecnológico (DESUSTEC) como herramienta en el desarrollo de software para la reducción de basura electrónica}

\author{
CENDEJAS-VALDEZ, José Luis ${ }^{1,3 *}$, FERREIRA-MEDINA, Heberto ${ }^{2} \dagger$, VANEGAS-CONTRERAS, \\ Gustavo A. ${ }^{3}$ and ACUÑA-LÓPEZ, Miguel Á. ${ }^{3}$ \\ ${ }^{1}$ Universidad de Morelia. Posgrados Tecnologías de la Información \\ ${ }^{2}$ Universidad Nacional Autónoma de México. Instituto de Investigaciones en Ecosistemas y sustentabilidad \\ ${ }^{3}$ Universidad Tecnológica de Morelia. Tecnologías de la Información y Comunicación \\ ID $1^{\text {st }}$ Author: José Luis, Cendejas-Valdez / ORC ID: 0000-0002-4109-4053, CVU CONACYT ID: 345997 \\ ID $1^{\text {st }}$ Coauthor: Heberto, Ferreira-Medina / ORC ID: 0000-0003-0150-2355, CVU CONACYT ID: 67744 \\ ID $2^{\text {nd }}$ Coauthor: Gustavo A, Vanegas-Contreras / ORC ID: 0000-0003-0152-3682, CVU CONACYT ID: 644069 \\ ID $3^{\text {rd }}$ Coauthor: Miguel Á, Acuña-López / ORC ID: 0000-0002-6289-1713, CVU CONACYT ID: 644394
}

\begin{abstract}
Currently technology is an engine for organizations and the human being to be more productive, based on this scoop there is a need for organizations to have areas that improve their processes through research, development and innovation $(\mathrm{R}+\mathrm{D}+\mathrm{i})$. Enriching their ways of work, staff and society. However, in recent years, the lack of interest in caring for the environment and the lack of proper environmental education has resulted in not leaving a better living condition for future generations. The elements that contribute to this are the excessive use of technology, technological consumerism, the inappropriate use of computers and the disposal of mobile devices; What has resulted that the planet is affected every day with the generation of electronic garbage contributing directly to global warming. Companies that develop software require greater hardware resources so that their applications work in the best way, which generates a limited life time in the devices and that the software that is built requires more resources for its optimal operation; thus, advancing the useful life and becoming technological waste.
\end{abstract}

Software, Sustainability, Electronic waste, Social responsibility, DESUSTEC

\begin{abstract}
Resumen
Actualmente la tecnología es un catalizador para que las organizaciones y el ser humano sean mas productivos, con base en esta primicia existe la necesidad de que las organizaciones cuenten con áreas que mejoren sus procesos a través de la investigación, desarrollo e innovación $(\mathrm{I}+\mathrm{D}+\mathrm{i})$. Enriqueciendo así sus formas de trabajo, personal y social. Sin embargo, en los últimos años el desinterés en el cuidado del medio ambiente y la falta de una educación ambiental apropiada ha generado el no dejar una mejor condición de vida para las próximas generaciones. Los elementos que contribuyen en ello es el uso desmedido de tecnología, el consumismo tecnológico, el uso inadecuado de computadoras y el desecho de dispositivos móviles; lo que ha dado como resultado que día a día se afecte al planeta con la generación de basura electrónica contribuyendo de manera directa en el calentamiento global. Las empresas que desarrollan software exigen mayores recursos de hardware para que sus aplicaciones funcionen de la mejor manera, lo que genera un tiempo de vida limitado en los dispositivos y que el software que se construye exija mayores recursos para su óptimo funcionamiento; adelantando así la vida útil y convirtiéndose en basura tecnológica.
\end{abstract}

Software, Sustentabilidad, Basura electrónica, Responsabilidad social, DESUSTEC

Citation: CENDEJAS-VALDEZ, José Luis, FERREIRA-MEDINA, Heberto, VANEGAS-CONTRERAS, Gustavo A. and ACUÑA-LÓPEZ, Miguel Á. The sustainable technological model (DESUSTEC) as a tool in the development of software for the reduction of electronic waste. Journal of Technology and Innovation. 2019, 6-18: 5-15.

\footnotetext{
* Correspondence to Author (email: luiscendejas@ hotmail.com)

$\dagger$ Researcher contributing first author
} 


\section{Introduction}

Sustainability is increasingly important in the essential process of organizations, today it is necessary that the products or services that are marketed throughout the world bear the stamp of green technology, estimated according to data from the STEP initiative (Solving the ewaste problem) that each inhabitant in Mexico produces an estimated 7 to 9 kilograms of electronic waste per year, which is estimated that globally in 2018 generated 49.8 billion tons of electronic waste (STEP, 2015).

Including to a large extent those dedicated to software development, because the projects that are currently being developed require large amounts of hardware resources; which makes them have a useful life of a few years due to the demand for storage, consumption of memory and processing power.

Within the technological companies can be found the software factories which generate their products and services in the cloud based on methodologies and processes that traditionally do not take into account the economic or ecological sustainability of the same, which results in that the devices and electronic devices that they implement have a useful life of approximately 2 to 4 years, that is, they are manufactured with the idea that mobile devices are obsolete in a short time and therefore promote consumerism (Asociación Mexicana de Internet, 2014), (Ferreira, 2015), (Greenpeace, 2005), (Ramírez P. , 2012).

It has been observed that with the passage of time the software of the devices becomes obsolete and this no longer has any support to update itself. This study proposes the construction of a sustainable software development model that not only includes steps or stages to be followed under a sustainable approach; but the use of environmentally friendly technology that allows hardware devices to extend their lifespan by at least 10 years.

In addition to review methodological proposals, models and / or methodologies for the agile development of software that contribute with the programmers towards a social approach, which are oriented in the sustainability and the attributes that should have.
With this research, a proposal is presented so that the companies dedicated to software development have a methodological technological framework (DESUSTEC) with a sustainable approach. DESUSTEC must meet the needs of the technological environment and care for the environment in a responsible manner, make use of technology and support sustainable development; so that it will allow the development of the means for future generations to inherit better natural resources than today. The demand in the market for the development of applications (software) that run on local computers (desktop computers) or on mobile devices (APPs), has fostered a boom in software development in the world. Therefore, there is a need to improve and innovate in any type of applications, which must be faster and easier to elaborate.

Therefore, there is a need to present a model that provides a dual role for society that is concerned about caring for the environment and immersed in the use of technology, on the one hand providing 1) sustainable elements in both hardware and software, which will help generate a strategy or regulatory framework in the construction of custom software. In order to comply with one of the goals or objectives of this proposal, which is to build software with a useful life of more than ten years in the market, this will allow greater demands on more hardware resources (memory and processor speed) of the devices where the developed software is used. And on the other hand 2) contribute to the care of the environment through the generation and reduction of electronic waste.

\section{Literature Review}

In this section a set of elements are integrated that allow building software in an agile and sustainable way, looking for the care of the environment accompanied by the reduction of electronic waste.

\section{i. Global warming}

From the industrial revolution, in the eighteenth century, human activities (industry, manufacturing, vehicles ...) have contributed dramatically to increase the presence of carbon dioxide (CO2) in the atmosphere. 
The warming of the Earth has been generated due to these human activities to this phenomenon is called global warming. (Isaza D., 2007)

The term Global Warming refers to the gradual increase in the temperatures of the atmosphere and oceans of the Earth that has been detected at present, in addition to its continuous increase that is projected in the future. No one questions the increase in global temperature, which still generates controversy is the source and reason for this increase in temperature. Even so, most of the scientific community ensures that there is more than $90 \%$ certainty that the increase is due to greenhouse gas concentrations due to human activities such as deforestation and the burning of fossil fuels such as oil, coal and technological waste. These conclusions are supported by the science academies of most industrialized countries.

Other effects would include more frequent extreme weather, which includes droughts, heat waves, hurricanes and heavy rainfall. Extinction of species is expected due to temperature changes and strong variations in crop yield.

The increase in global average temperature is higher than $4^{\circ} \mathrm{C}$ compared to preindustrial temperatures, in many parts of the world and natural systems will not be able to adapt and therefore will not be able to support their surrounding populations. In short, there will be no natural resources to sustain human life under current conditions. In figure 1 it can be observed in which elements of the earth is where the warming of our planet concentrates most.

\section{Where is the energy being stored?}

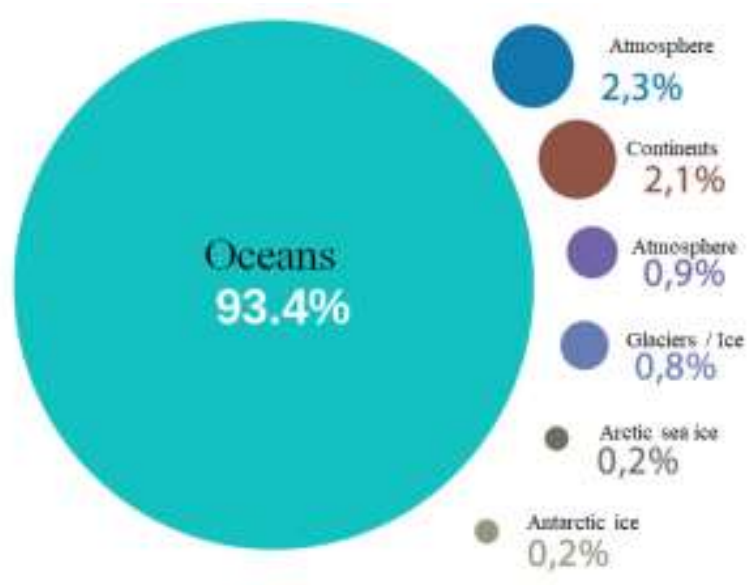

Figure 1 Concentration of global warming

Source: Moreno, Cerutti \& Gutiérrez (2014)

ISSN 2410-3993

ECORFAN® Todos los derechos reservados
Hence, there is a need to pay attention to this problem and attention to see how it can contribute to its solution and every time we discard, buy or make use of new technology contributes to the development of global warming.

\section{ii. Earth Charter}

The Earth Charter is a declaration of fundamental principles for the construction of a global society in the XXI Century, which is fair, sustainable and peaceful. In October 2003, the United Nations for Education (UNESCO) resolved "Recognize that the Earth Charter constitutes an important ethical reference for sustainable development, and express its support for the contents of said Charter".

For this reason, within the "UNESCO Decade for Sustainable Development (20052014)", approved in December 2002 by the General Assembly of the United Nations (UN), in April 2005 the Charter of the Earth has been incorporated into the International Application Project of the United Nations Decade of Education for Sustainable Development (ESD), as an invaluable educational tool. (Martín, 2005)

The Earth Charter initiative has entered a new phase, which focuses on bringing these principles into action. For this, the Mexican government declared its support during the World Summit for Sustainable Development, held in Johannesburg, South Africa, for which Mexico is the National Committee for the Earth Charter operated by a National Secretariat, with the purpose of crystallizing the objectives of the Type II Alliance, "Educating for a Sustainable Lifestyle with the Earth Charter".

Hence, in the XIV principle, the relationship between this document and the use of technology is very well linked, which says the following: Integrate in formal education and lifelong learning, skills, knowledge and values necessary for a sustainable way of life.

This is that not only should you buy and consume technology but be concerned about being responsible for the use that will be given to that technology after having taken advantage of it and giving it an appropriate use from cradle to death (recycling). 


\section{iii. Sustainability}

At this point comes a very important concept that is sustainable or sustainable, the concept that most interests, due to the relationship that information and communication technologies (ICT) have with companies and the environment is the concept of sustainability business "Business sustainability" is a new paradigm in the management of companies.

It is an alternative to the traditional growth model and maximization of profitability (Wilson, 2003). Sometimes this term is used as a whole and as a synonym of others such as sustainable development (DS) and corporate social responsibility (CSR). However, neither of these two concepts defines business sustainability on its own, but rather the combination of both that manages to formulate a new trend in companies (Portales y Garcíade-la- Torre, 2009).

There are different concepts of sustainability that have been modified in recent decades. But an intergenerational concept is the one presented by Sánchez, García \& Ramírez (2004), where they comment that this focus on sustainable development refers to the need to preserve nature, so that future generations maximize their options in their use and increase your well-being.

The definition focuses on the responsibility of the current generation with respect to future ones. Sustainable development consists of being fair to the future, so that the present generation must develop the means for future generations to inherit the same resources that are now available. It is argued that it is natural for humanity to fight for the continued growth of production and consumption.

The basic idea is that economic growth is a necessary condition to increase protection and environmental renewal. Economic growth is considered vital for the sustainable development of the world. Sustainability includes some elements that must be taken into account for their optimal functioning, among them we find:

\section{a. Resource efficiency}

The concept of "efficient use of resources" generates more value by using less materials and consuming in a different way.
In this way, the risk of scarcity is reduced, and the environmental impacts will remain within the natural limits of our planet. 2020 aims to increase security for investment, innovation and create opportunities for sustainable economic growth, ensuring that all relevant policies take into account the efficiency of resources in a coherent manner. (Europea, 2011).

\section{b. Quality of life}

What is meant by the term Quality of life, the expression quality of life appears in public debates about the environment and the deterioration of urban living conditions. The concept can be used for a number of purposes, including the assessment of the needs of people and their levels of satisfaction. (Castillo, 2016).

\section{c. Company - competitiveness}

To improve competitiveness, companies must adapt their strategies and organizational structure to the dynamic environment of today's economy. The success of the company will depend to a large extent on its capacity to acquire adequate resources and skills to achieve new competitive advantages (quality, technological capacity, innovation, human capital, knowledge, etc.), with the permanent objective of growth and diversification. (Ponce, 2016).

\section{d. Social responsability}

The issue of Social Responsibility at an international and national level is becoming more and more popular among the Organizations due to the awareness and need to maintain a socially responsible behavior that allows contributing to Sustainable Development. (Romero, 2016)

\section{iv. Impacto de la tecnología en el medio ambiente}

In the context of current globalization, no industrial, commercial or service policy, like the social one, will succeed if it does not know the need to incorporate the principles of sustainable development as guides to economic growth. Many of the environmental technologies can help improve the natural environment while boosting the competitiveness of companies.

CENDEJAS-VALDEZ, José Luis, FERREIRA-MEDINA, Heberto, VANEGAS CENDEJAS-VALDEZ, José Luis, FERREIRA-MEDINA, Heberto, VANEGAS-
CONTRERAS, Gustavo A. and ACUÑA-LÓPEZ, Miguel Á. The sustainable technological model (DESUSTEC) as a tool in the development of software for the
to reduction of electronic waste.. Journal of Technology and Innovation. 2019 
However, there are still limitations in terms of its development, such as the complexity to move from traditional technologies to more modern ones, and access to capital.

The Science and Technology strategy has been considered fundamentally and important to lay the foundations for a new articulation between all sectors; including the environmental. Therefore, scientific and technological development should be oriented to improve the existing socioeconomic situation, using the human potential and the natural resources that are possessed with a long-term and integral vision. (Peñaloza, Arévalo \& Daza, 2009).

Recently, the sociocultural environment of users has become important in the rethinking of the technological paradigm. Puchet \& Bolaños (2005) describe ecotechnology within a conceptual framework of thought in which it is essential to take into account the life of the technological user, their individuality and their value judgments. In his proposal he exposes that technology is not universally adaptable and therefore needs to be designed according to human contexts in which subjectivity is present. In this way, it reinforces the idea that to introduce an ecotechnology to a specific context it is necessary to generate acceptance mechanisms that take into account the locality, culture and ways of living of the users.

Although the original conceptualization of ecotechnology focused on the management of ecosystems, the systemic vision was incorporated into the industry, later the attention jumped from the productive sector to the consumer sector and users of technology. The eco-technological discourse has thus benefited from different conceptual contributions and has evolved since its emergence, it is an area of exact, predictive and quantitative knowledge, towards a notion that involves social and economic criteria, as shown in Figure 2.

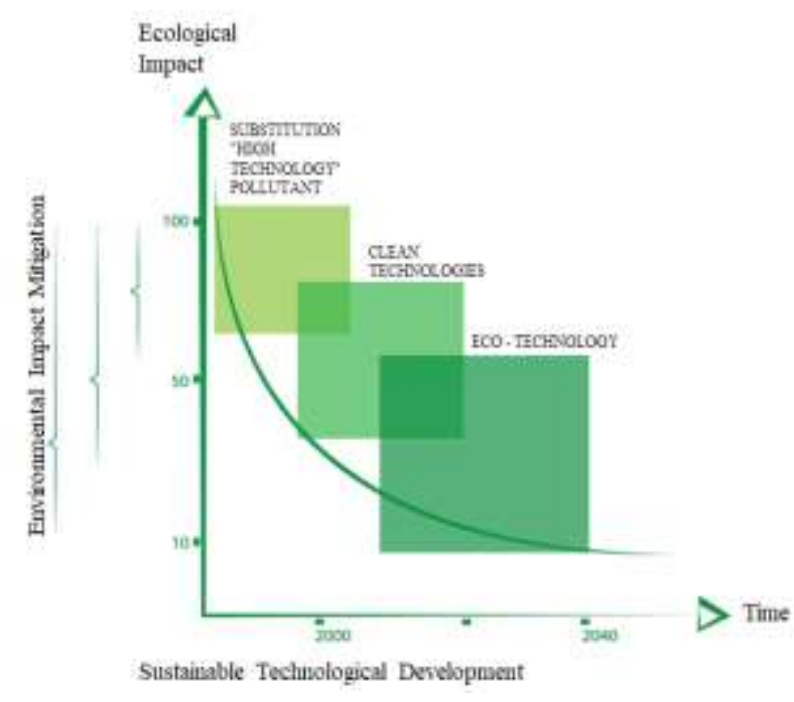

Figure 2 Technological transition proposed by MOSER Source: MOSER (1996)

\section{v. Research, development and innovation}

Research and Development ( $R \& D$ ) are two scientific and technological activities of great value because they involve the creation of new knowledge, a key element for the general progress of society.

If we add to them the practical application of progress through Innovation, we will have the complete cycle of a research system. In the Knowledge Society, the Research, Development and Innovation cycle $(\mathrm{R}+\mathrm{D}+\mathrm{i})$ occupies a strategic position, as it promotes economic growth and business competitiveness in a markedly dynamic international environment. (Pujol \& Vivó, 2008)

The acquisition and generation of new or relevant knowledge for any organization can occur through: Development of research and
experimentation: includes the creative
work that is undertaken on a systematic
basis in order to increase the knowledge
pool. Most of the time, the most
important experimental phase is the
construction and testing of a prototype,
that is, an original model that includes
all the characteristics and technical
achievements of a new product or
process. 
Acquisition of unincorporated technology and knowledge: includes obtaining external technology in the form of patents, non-patented inventions, licenses, disclosures of know-how, designs, trademarks, patterns, as well as computer services and other scientific services and technicians related to the implementation of innovations, in addition to the acquisition of software packages not classified elsewhere.

\section{vi. Information and communication technologies}

Information and Communication Technologies (ICT) are all those resources, tools and programs that are used to process, manage and share information through various technological supports, such as: computers, mobile phones, televisions, portable audio players and video or game consoles. (Puchet \& Bolaños, 2015), within these technological tools, we can take into consideration some of them as they are:

\section{a. Ecotechnologies}

Ecotechnologies are defined as the use of technological means to manage ecosystems, based on an in-depth knowledge of the principles on which natural ecological systems are based and the transfer of this knowledge towards their management in a such that the damage caused to the environment is minimized.

Likewise, ecotechnologies are defined as techniques that attempt to solve the daily needs of the life of human beings with an ecological perspective; Its application aims at the optimal and efficient use of energy and the improvement of domestic, industrial and labor processes. (Barcenas, 2010).

\section{b. Virtualization}

In general terms, virtualization is a process and result of data processing through computer, information and knowledge. More specifically, virtualization consists of electronically and digitally representing objects and processes that we find in the real world.
In the university context, virtualization can include the representation of processes and objects associated with teaching and learning activities, research and management, as well as objects whose manipulation allows the user to perform various operations through the Internet, such as learning through the interaction with electronic courses, enroll in a course, consult documents in an electronic library, communicate with students and teachers and others. (QUÉAU, 1993)

c. Free software

With free software reference is made to the freedom of the users to execute, copy, distribute, study, change and improve the software. Free software is any program whose users enjoy these freedoms. So it should be free to redistribute copies with or without modifications for free or charge for distribution, to anyone and anywhere.

The freedom to use a program means that any individual or organization can execute it from any computer system, for any purpose and without the obligation to communicate it subsequently to the developer or to any specific entity. The freedom to redistribute copies supposes to include the binary or executable forms of the program and the source code of both the modified versions and the original ones.

Free software does not mean that it is "non-commercial". Any free program will be available for use, development and commercial distribution. The commercial development of free software has stopped being exceptional and in fact that commercial free software is very important. (Stallman, 2004).

\section{vii. Model for the development of collaborative integral software (MDCIS)}

In (Cendejas, Vega, Careta, Gutierrez \& Ferreira, 2014) a Model for the Development of Collaborative Integral Software (MDCIS) is proposed, which is oriented to the rapid development of applications and that is a necessity of the micro, small and medium companies (SMEs) of the Central-West Zone of Mexico. 
This model proposes an easy and simple way for the rapid development of applications and custom software, the objective of this methodology is to be a reference and enable competitiveness for the software factories in the region. This project presents the design of a methodology based on the experience of the industry in the Central-Western region of Mexico, the methodology will allow a development adhering to standards and the needs of companies that are immersed in this new type of development of software. Through MDCIS, quality products will be provided allowing the control and administration of the software project.

\section{- $\quad$ Sustainable software \\ - $\quad$ Linking with software factories \\ - $\quad$ Impact on the productive sector \\ - $\quad$ Training of human resources}

In Cendejas et al. (2014), it is mentioned that the main problem of software development is the development of quality products that meet the needs and objectives of organizations. In addition, the software that is developed is not aligned with the objectives and goals of the organization, ie the software is only developed by IT experts who are dedicated to perform an analysis, design and development of it, but never it is accompanied by experts from the organizational processes that benefit the development of the product in a formal way.

The model defines 5 different levels that provide the best practices for software development, using the best practices of the Project Management Institute (PMI) in planning, which allows generating quality software aligned with the strategy of the organization, see figure 3 .

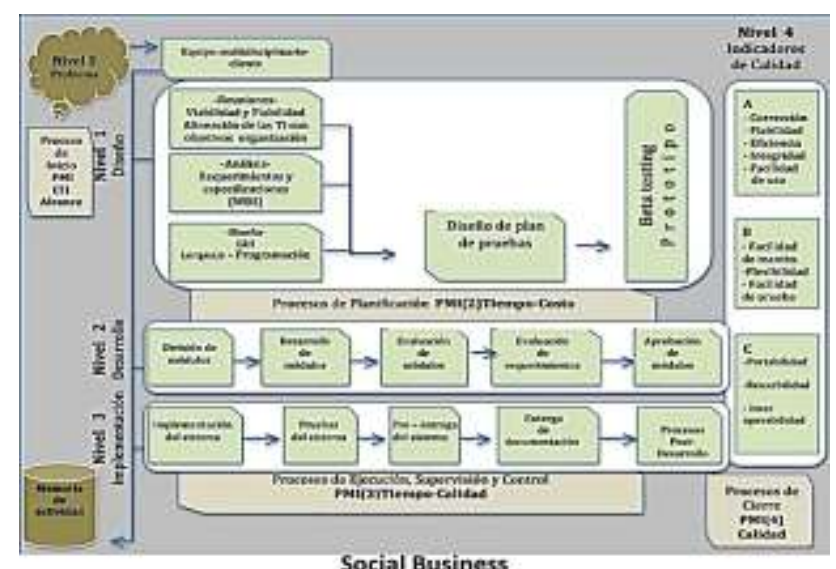

Figure 3 Integral, Collaborative Software Development Model (MDCIS)

Source: Cendejas et al. (2014)
MDCIS evaluates the quality of the software through indicators that validate its operation, these indicators are contemplated in international quality standards. Finally, the MDCIS seeks to generate a knowledge base through social business and social networks, generating an information bank that allows best practices in the development of software projects.

This model is called collaborative integral since the participation of the characters that intervene in the development should generate a collaborative and integral environment between the developers and the participants (stakeholders) of the project.

In the model, the first five PMI elements are integrated:

\author{
Integration of projects. \\ Scope. \\ Weather. \\ Cost. \\ Quality.
}

With this, what is sought is to develop the best practices to open, develop and close a project. The model offers the following advantages to users:

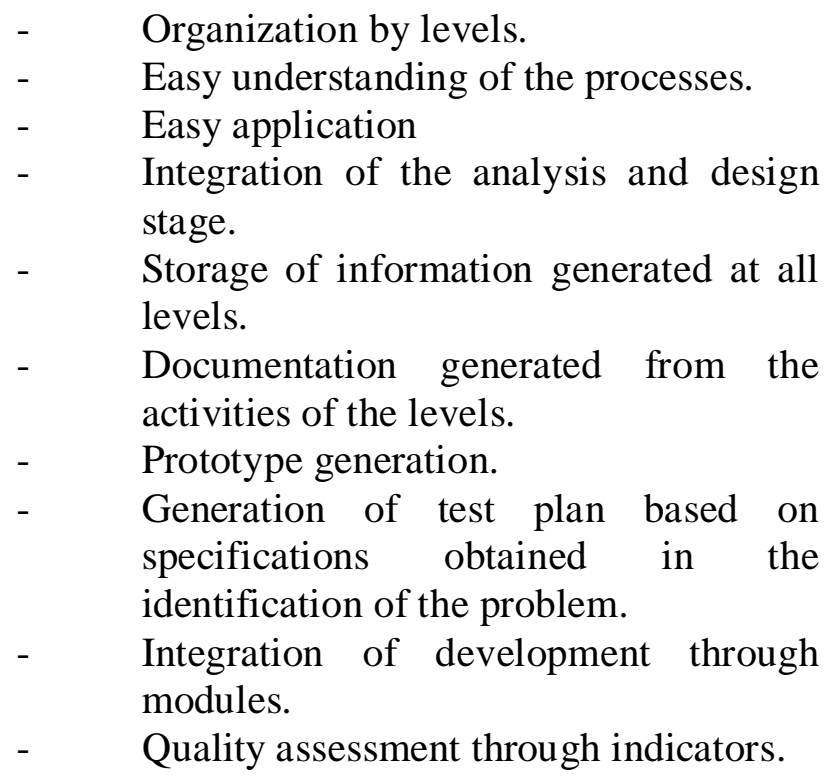

\section{Methodology}

Once the problem to be resolved has been identified and the objectives to be met have been established, this section describes the research context, in which the procedures required to obtain the necessary information and to structure or solve the research problem are defined.

CENDEJAS-VALDEZ José Luis, FERREIRA-MEDINA, Heberto, VANEGASCONTRERAS, Gustavo A and ACUÑA-LÓPEZ Miguel Á. The sustainable technological model (DESUSTEC) as a tool in the development of software for the reduction of electronic waste.. Journal of Technology and Innovation. 2019 


\section{i. Nature and approach of the investigation}

Based on what is explained in the following sections, the nature of the research in this paper has a scope of type: 1) Transectional because, as stated by Hernández, Fernández and Baptista (2006), the purpose of the research is to describe variables and analyze their incidence and interrelation at a given moment, that is, the research data will be collected only once. 2) Descriptive involves the critical review and analysis of the most relevant results that have been achieved in previous research, the conceptual problems and their methodological limitations, the unresolved issues, the possibilities of future development and the directions in which progress must be made to produce an improved and broad knowledge (Sarabia Sánchez, 1999). 3) Correlational is a type of descriptive study, which aims to determine the degree of relationship or noncausal association between two or more variables. It is characterized because it first measures the variables and then, performs the application of statistical techniques, which allows to measure the correlation. 4) Documentary, this type of research is a process that, through the application of scientific methods, seeks to obtain relevant, reliable and impartial information to extend, verify, correct or apply knowledge. 5) Analysis - Synthesis, all phenomena that are presented to the consideration of man are too complex if they are examined carefully. They are simple only at first sight. If you want to investigate the causes, it is necessary to separate the phenomenon in parts to study it in a better way. Scientific research is not immune to these procedures.

\section{ii. Methodological model}

The research design consists of generating a series of steps to follow to achieve the general objective and the goals set; which are the following:

1) Research proposal by research professors presenting the DESUSTEC model. As well as the Feasibility of the investigation, to know if the feasibility exists in developing this proposal in the context of Mexico and America.

2) Design of the research, make up the work team and the different stages in which the project will be developed.
3) Analysis - synthesis of the information that sustains the present investigation will be carried out (review of the literature).

4) Integration of sustainable tools, that do not harm the environment in a sustainable way.

5) DESUSTEC design, feedback and improvement adjustments.

6) Training of students with IT profile, creation of the software cell by students of the UDEM. Based on the foundations proposed for the research, the methodological model of the proposed research is presented in figure 4 , as well as the stages to follow.

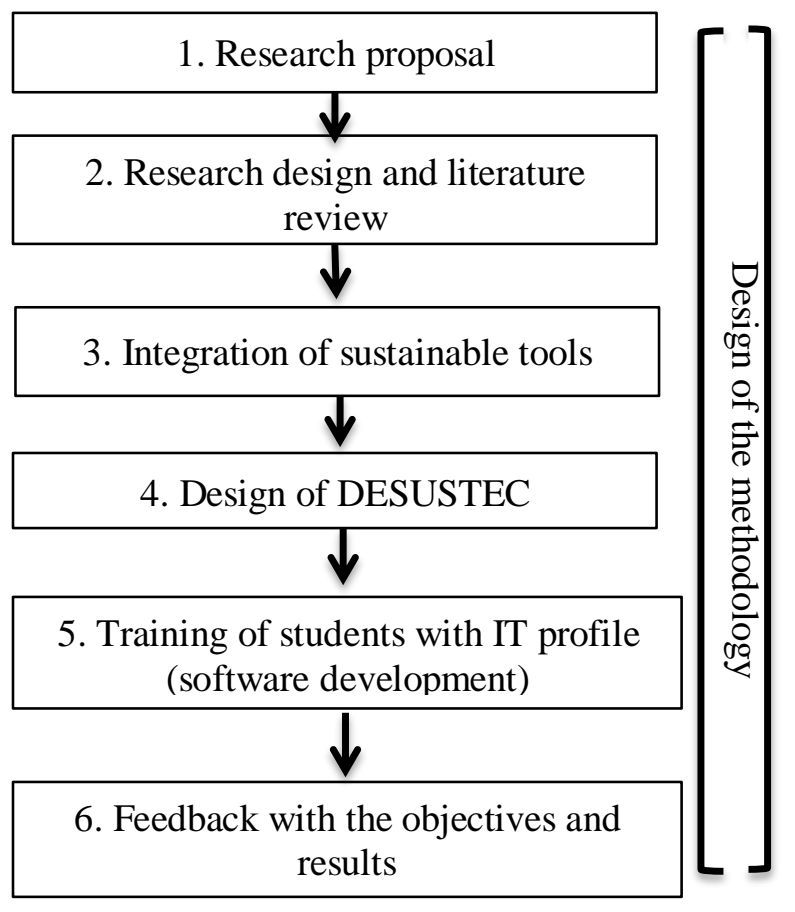

Figure 4 Research model - proposed Source: propia (2015)

\section{iii. Statistical study}

Based on what was proposed by Álvarez (2017), in the study related to the construction of sustainable software, 72 professionals were interviewed in public and private universities in the central-western region of Mexico.

Once it was carried out, it was analyzed, where the coefficient of the Alfa Cronbach was obtained with a value of 0.737 which indicates an acceptable internal consistency in the results of the survey and through a study of Pearson correlations the most significant were obtained present values $>=0.5$, which are detailed in table 1 .

CENDEJAS-VALDEZ, José Luis, FERREIRA-MEDINA, Heberto, VANEGAS CONTRERAS, Gustavo A and ACUNEA-LÓPEZ Miguel Á. The sustainable technological model (DESUSTEC) as a tool in the development of software for the reduction of electronic waste.. Journal of Technology and Innovation. 2019 


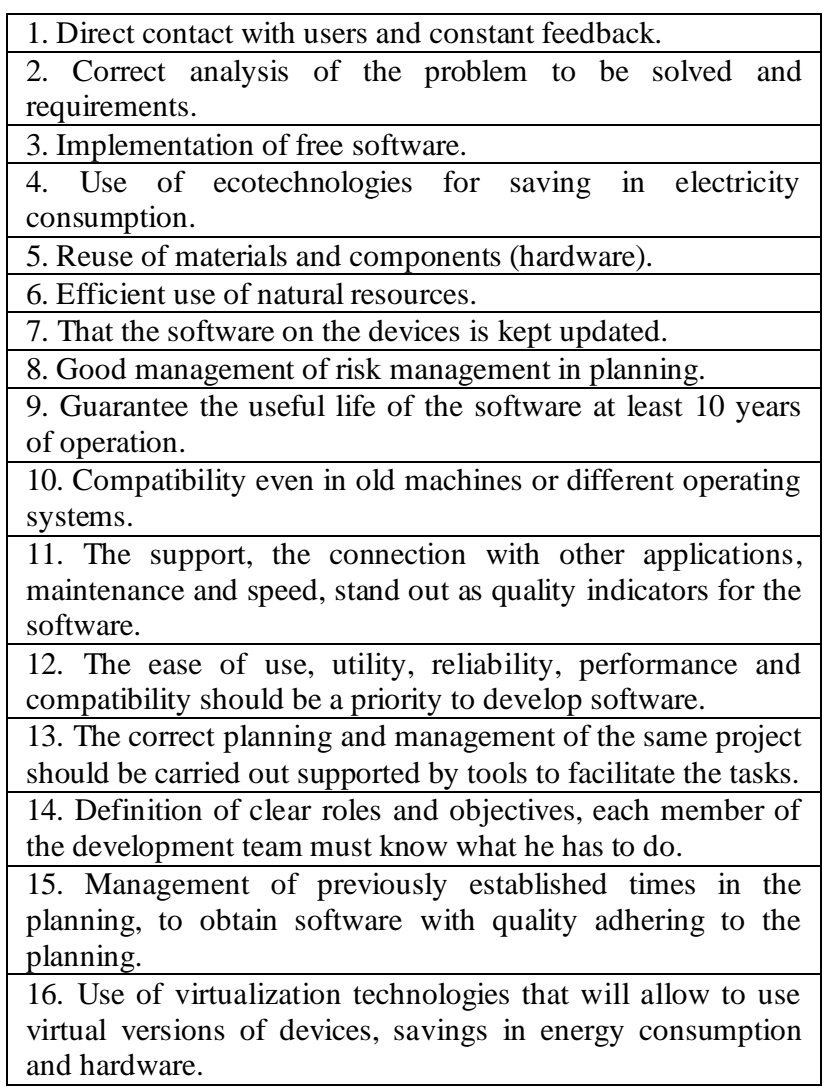

Table 1 Significant correlations in the construction of sustainable software

Source: Álvarez (2017)

\section{Results}

Based on the foundations presented previously in the present investigation, the five levels that make up the DESUSTEC model and the way it is integrated and should function are proposed.

The functioning of DESUSTEC begins through a) Level 1, which presents the conformation of a software cell formed by engineering students with a profile related to the area of tic's, which will receive previous training related to the development of custom software; this with the aim of serving as a specialized human resource for companies and factories that are dedicated to software development and to be trained in aspects related to the care of the environment and the responsible use of technological development.

b) Level 2, refers to the use of the model for the development of collaborative comprehensive software (MDCIS), which serves as a practical and agile guide that contributes to the development of custom software. This to be able to count on a methodological process that helps to obtain optimum levels of quality and the total satisfaction of the client. c) Level 3, in a very special way, refers to the technological proposal, which reflects the use of three elements that are currently of vital importance and that help the development of software efficiently, with a sustainable approach and care for the environment. These elements are: a) Use of solar energy through solar panels that allow the turning on and powering of computers, mobile devices and Internet access necessary to develop software in an agile and customized way. b) Use of virtualization and storage through computers that integrate several processors and several storage volumes (hard disks) that allow the support of programming languages in different platforms (IOS, Android, Windows, Linux) and databases that avoid the excessive use of equipment, with the aim of impacting global warming with the work of different computers and mobile equipment. c) Use of free software, the main advantage that is had when generating software through this type of license is beneficial for the software industry since it is not required to make any payment for its use and / or license. In addition to that many of them have support and are powerful for the development of computer systems such as ERP, CRM and business systems. You can mention swift, android studio, php, mysql, perl, python, among others.

d) Level 4, it is important that after each software development based on the previously integrated elements the quality evaluation is carried out through eleven indicators that help to measure the efficiency of the manufactured software.

e) Level 5, at this level we seek to obtain software products that are friendly to the environment; this is that at least they have a useful life of at least ten years and that they avoid the use and waste of hardware elements of mobile devices; what will generate electronic garbage.

And finally the f) Level 6 aims to reduce the amount of electronic garbage that is generated through cell phones, tablets, servers, laptops and personal computers; which are generated by the users due to the need for more resources required by the software in the equipment to be installed. The levels that integrate and base the DESUSTEC, are reflected in a graphic way in figure 5. 


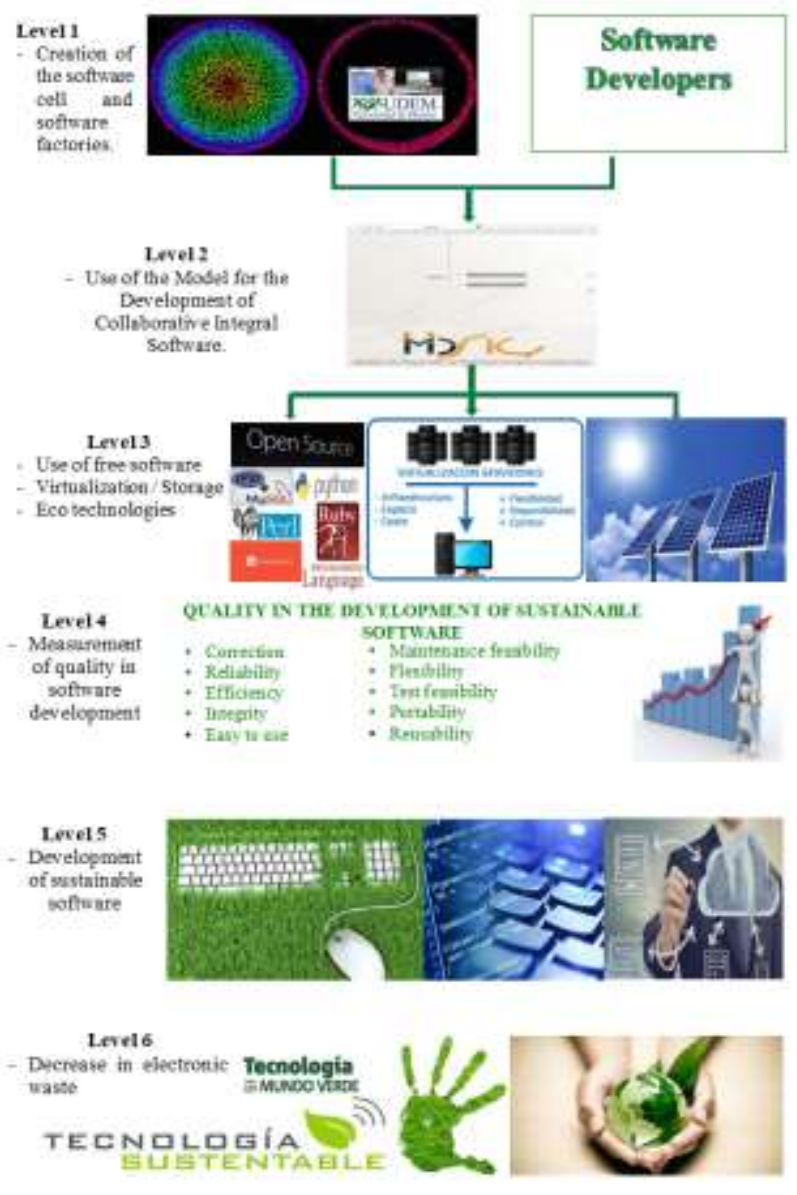

Figure 5 DESUSTEC model - proposed Source: Own (2019)

\section{Conclusions}

Electronic waste is a problem that must be addressed immediately and one solution is to be able to develop software under a sustainable approach; making use of ecotechnologies, virtualization - storage and open source programming languages (free software). What would allow to develop software tailored to quality and with a lifespan of at least ten years.

According to the methodologies and / or agile models consulted for software development, no one takes sustainability into account, so this represents an advantage with respect to them.

The technology developed under the proposed model may be marketed as a green technology. It encourages energy saving, implementing eco-technologies which represents a competitive advantage for organizations, as well as a reduction in production costs and time. Since one of the main pillars of the proposal is the code reuse to streamline the creation of software.
It is intended to generate a uniform infrastructure in the future that allows the creation of microservices in a sustainable manner, thus offering software as a service (SaaS), that is, a uniform architecture that encompasses all the technologies that are scattered today and that allow the generation of sustainability. in software development. Helping users to develop software quickly and with quality.

In turn, the proposed model may be a sustainability framework applicable to technological projects, even in other areas of knowledge. Nowadays, the legal framework begins to request in several countries that companies consider ethically and socially sustainability in their processes for the generation of their products and / or services.

\section{References}

Álvarez G., O. A. (2017). Desarrollo de una propuesta metodológica para la construcción de software (tesis de ingeniería). Universidad tecnológica de Morelia, México.

Asociación Mexicana de Internet, Dispositivos Móviles: Hábitos del consumidor Mexicano, 2014. [En línea]. Available: https://www.amipci.org.mx/images/Estudio_Di spositivo_moviles_2014.pdf. [Último acceso: 26 Octubre 2016].

Castillo, D. M. (21 de marzo de 2016). Calidad de vida. Revista Mexicana de Medicina Física y Rehabilitación, 5-6. Obtenido de http://www.medigraphic.com/pdfs/fisica/mf2006/mf061 a.pdf

Cendejas V., J. L., Vega Lebrún, C. A., Careta Isordia, A., Gutierrez Sánchez, O., \& Ferreira Medina, H. (2014). Design of the integrated collaborative model for agile development software in the central-western companies México. Nova Scientia, 1-12.

Europea, U. (abril de 2011). Utilización eficiente de los recursos: un imperativo para las empresas. Obtenido de http://ec.europa.eu/environment/resource_effici ency/documents/factsheet_es.pdf

Ferreira M. H., «Metodología MDCIS-M para el desarrollo de aplicaciones móviles en empresas Pymes,» 2015. [En línea]. 
Greenpeace, Recycling of electronic wastes in China and India: Workplace and environmental contamination, 2005. [En línea]. Available: http://www.greenpeace.org/international/Global /international/planet-2/report/2005/10/recycling -of-electronic-waste.pdf. [Último acceso: 16 Enero 2017].

Hernández S., R.; Fernández-Collado, C. \& Baptista L., P. (2010). Metodología de la investigación. México: McGraw-Hill.

Isaza D., José Fernando (2007). Cambio Climático Glaciaciones y calentamiento global. Bogotá Colombia: Fundación Universidad de Bogotá Jorge Tadeo Lozano.

Martín, M. d. (2005). La Carta de la Tierra: instrumento para la educación en desarrollo sostenible. Sumario, 41-57.

Moreno, J. A. O., Cerutti, O. R. M., \& Gutiérrez, A. F. F. (2014). La ecotecnología en México. IMAGIA.

Peñaloza Acosta, M., Arévalo Cohén, F., \& Daza Suárez, R. (2009). Impacto de la gestión tecnológica en el medio. Revista de Ciencias Sociales (Ve), 306-316.

Ponce, M. D. (21 de marzo de 2016). Ensayo a cerca de los factores que influyen en la empresa. Obtenido de http://www.gaedpyme.upct.es/informe0101.php

Portales, L. y García de la Torre, C. (2009). La penta-dimensionalidad de la sustentabilidad: un modelo para la PYME en México. 1er. Congreso Internacional en México sobre la MIPYME. Pachuca: Consorcio de Universidades Mexicanas (CUMEX) y la Universidad Autónoma del Estado de Hidalgo UAEH, en colaboración con la Association Internationale de Recherche en Entrepreneuriat et PME (AIREPME).

Puchet Anyul C. \& Bolaños S. UNAM. (2015). Las TIC para aprender - Guía didáctica. Obtenido de http://www.comoves.unam.mx/ assets/revista/205/guiadelmaestro_205.pdf

Pujol, E. F., \& Vivó, L. A. (2008). I+D+I: UNA PERSPECTIVA DOCUMENTAL. Anales de documentación, 43-56.
QUÉAU, P. (1993). Le Virtuel. En P. QUÉAU, Le Virtuel. París: Editions Champ Vallon et INA.

Ramírez P., Obsolescencia tecnológica programada, Facultad de ciencias y tecnología, Universidad Catolica Sede Regional Asunción, http://jeuazarru.com/wpcontent/uploads/2014/1 0/obsolescencia_tecnologica_programada.pdf, 2012.

Romero, M. A. (21 de marzo de 2016). Nueva norma iso 26000:2010 responsabilidad social. Obtenido de http://www.globalstd.com/pdf/rsiso26000-2010.pdf

Sánchez Núñez, J. M.; García Camacho, A.; Ramírez Treviño, A.; (2004). El Desarrollo Sustentable: Interpretación y Análisis. Revista del Centro de Investigación. Universidad La Salle, julio-diciembre, 55-59.

Sarabia Sánchez, Francisco José (1999). Metodología para la Investigación en Marketing y Dirección de Empresas. Piramide, España.

Software libre para una sociedad libre. (2004). En R. M. Stallman. Traficantes de Sueños.

STEP, Solving the E-wast problem, 2015. [En línea]. Available: http://www.stepinitiative.org/Overview_Mexico.html. [Último acceso: 29 Marzo 2017].

Barcenas O., D. (2017). Diseño de indicadores técnicos y sociales para un protipo de vivienda rural sustentable en la microcuenca la joya (reporte de estadía Técnico Superior Universitario). Universidad tecnológica de Querétaro, México. Obtenido de: http://fcn.uaq.mx/crcc/docs/Diagnosticodelavivi enda.pdf

Wilson, M. (2003). Corporate sustainability: What is it and where does it come from? Ivey Business Journal, Marzo, 1-6. 